\title{
3D RECORDING METHODOLOGY APPLIED TO THE GROTTA SCRITTA PREHISTORIC ROCK-SHELTER IN OLMETA-DI-CAPOCORSO (CORSICA, FRANCE)
}

\author{
P. Grussenmeyer ${ }^{\mathrm{a}, *}$, A. Burens ${ }^{\mathrm{b}}$, S. Guillemin ${ }^{\mathrm{a}}$, E. Alby ${ }^{\mathrm{a}}$, F. Allegrini Simonetti ${ }^{\mathrm{c}}$, M.-L. Marchetti $^{\mathrm{c}}$ \\ ${ }^{\text {a}}$ Photogrammetry and Geomatics Group, ICube Laboratory UMR 7357, INSA Strasbourg, France \\ (pierre.grussenmeyer, samuel.guillemin, emmanuel.alby)@insa-strasbourg.fr \\ ${ }^{\mathrm{b}}$ Environmental Geography Laboratory, CNRS, UMR 5602 GEODE, Toulouse, France \\ albane.burens@univ-tlse2.fr \\ ${ }^{c}$ Collectivité territoriale de Corse, Direction de la culture et du patrimoine, Service des Patrimoines-Archéologie, Ajaccio, France \\ (marie-laurence.marchetti, fallegrini-simonetti)@ct-corse.fr
}

Session A1- Laser Scanning and 3D Imaging

KEY WORDS: Cultural Heritage, Prehistory, Rock art, Recording, Terrestrial, Photogrammetry, Laser Scanning, Accuracy

\begin{abstract}
:
The Grotta Scritta I prehistoric site is located on the west side of Cap Corse, in the territory of the municipality of Olmeta-diCapocorso (Haute-Corse, France). This rock shelter is located on a western spur of the mountains La Serra, at $412 \mathrm{~m}$ height above sea level. In the regional context of a broad set of megalithic burial sites (regions Nebbiu and Agriates) and a rich insular prehistoric rock art with several engraved patterns (mainly geometric), the Grotta Scritta is the only site with painted depictions of Corsica. Around twenty parietal depictions are arranged in the upper part of the rock-shelter and takes advantage of the microtopography of the wall. Today, the Grotta Scritta is a vulnerable site, made fragile by the action of time and man. The 3D scanning of the rockshelter and paintings of the Grotta Scritta was carried out by surveyors and archaeologists from INSA Strasbourg and from UMR 5602 GEODE (Toulouse), by combining accurate terrestrial laser scanning and photogrammetry techniques. These techniques are based on a full 3D documentation without contact of the rock-shelter paintings. The paper presents the data acquisition methodology followed by an overview of data processing solutions based on both imaging and laser scanning. Several deliverables as point clouds, meshed models, textured models and orthoimages are proposed for the documentation. Beyond their usefulness in terms of valorization, communication and virtual restitution, the proposed models also provide support tools for the analysis and perception of the complexity of the volumes of the shelter (namely for the folded forms of the dome housing the paintings) as well as for the accuracy of the painted depictions recorded on the orthophotos processed from the 3D model.
\end{abstract}

\section{INTRODUCTION}

In March 2014, a team of researchers from INSA Strasbourg (UMR 7357 ICube Laboratory) and from Toulouse (UMR 5602 Geode Laboratory) completed the 3D survey of the decorated site of the Grotta Scritta located in Olmeta-di Capocorso (Corsica, France). The municipality, owner of this archaeological site, ordered a 3D documentation for conservation, research and valorisation purposes. We present in this paper the historical and archaeological features of this exceptional site and the initial results from the imaging and laser scanning processing. The site's $3 \mathrm{D}$ scanning is an essential document to prepare the site classification request as an Historic Monument.

\section{PROJECT CONTEXT}

\subsection{Geographical description of the site}

The Grotta Scritta I site is located in Olmeta-di-Capocorso, the southernmost town of Cap Corse (Corsica, France) (Figure 1). The region is formed by a schistose dorsale range oriented in a north-south axis, relatively high and sharp ridges. The chain is characterized to the east and to the west by spurs and buttresses defining parallel valleys. The village of Olmeta-di-capocorso is implanted in one of them, open to the west of the Gulf of Saint-Florent and backed by the Serra.
The site is located on a spur of the western mountain range, at $412 \mathrm{~m}$ above see level. Overlooking the Mediterranean Sea, the site now dominates the beach of sand and black pebbles of Nonza and offers panoramic views of the Gulf of SaintFlorent. The visitor can access to the Grotta Scritta after a walk of $3 \mathrm{~km}$ from the village of Olmeta by the former path linking Olmeta to Nonza. It takes about one hour's walk on that way partially paved.

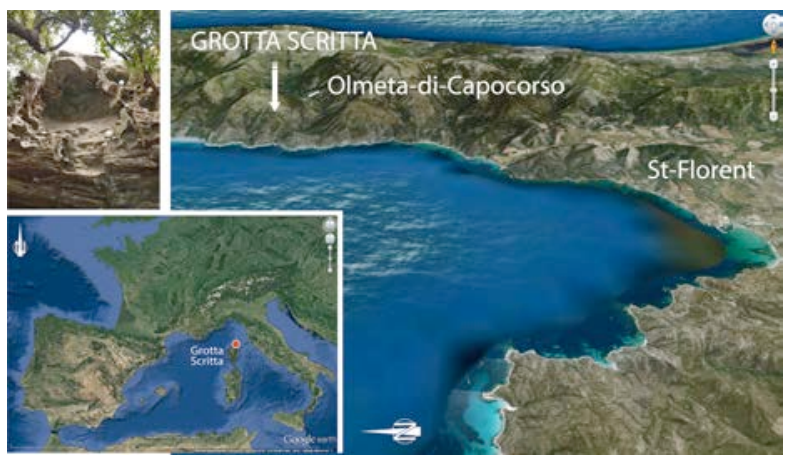

Figure 1. Location of the Grotta Scritta (Olmeta-diCapocorso, Corse, France) and focus towards the decorated dome (photo A. Burens)

* Corresponding author 


\subsection{The Grotta Scritta 1 site}

The Grotta Scritta 1 is the only site with painted depictions of Corsica. It actually corresponds to a natural rock shelter, facing west, forming a dome plumb of the rock face, just 2.50 $\mathrm{m}$ from the ground level. This cantilever of about $2 \mathrm{~m}$ wide is projecting over the cliff. 20 designs painted in red ochre and two engraved graffiti were discovered by R. Grosjean in the late 50s (Grosjean, 1959). No archaeological occupation could be directly involved. Another small shelter called "Grotta Scritta 2", until recently used by shepherds, is located a few meters below the site. The ceiling of the second shelter is covered with recent graffiti etchings.

The 20 listed parietal representations of the Grotta Scritta 1 rock face and the 2 recent graffiti occupy the top of the rock shelter, bathed in light in the evening. The painted patterns based on iron oxyde are unwrapped inside a dome having multiple small cavities, depressions and protrusions within a space of approximately $1,30 \mathrm{~m}$ wide by $0,70 \mathrm{~m}$ high. The patterns seem to take advantage of the micro-topography of the rock (Weiss, 2000). Among the main patterns, there are 7 anthropomorphic representations: 3 are represented with anthropomorphic or sexual caudal appendage (one of them bears horns, the other two have the arms raised or lowered), and 3 stylized anthropomorphic and a derivative of anthropomorphic. Two more complex patterns appear to include riders on their horses. Secondary signs are associated with the main ones: essentially points (or spots), lines, but also a broken line and a dotted line triangle. Two complex patterns composed of lines and points have been interpreted as comb-like patterns. Two modern graffiti have more recently been engraved nearby the paintings, inside the cupola. All painted patterns are distributed within different micro-reliefs of the cavity (a center panel, a plurality of cells and a depression). A timeline in 5 steps times describing the painted embodiment forms has been proposed by C. Weiss, on the basis of a differentiation of the color of the pigments used, production techniques and distribution of the representations on the rock (Weiss, 1998).

Apart from two recent graffiti, patterns painted on the Grotta Scritta 1 walls appear to be linked to a vast Mediterranean trend characterized by a postglacial schematic art which Spain is considered the center. We find in the Grotta Scritta some of the main principles governing this pictorial art: schematization and simplification of the figures, repeating patterns and their superposition or the combination and complementarity of some representations (Hameau,1995). A significant number of parallels was drawn between the painted representations of the Grotta Scritta I and rock and parietal ones well known in the Iberian Peninsula, in the Italian Piedmont, but also in Provence and Sardinia (Grosjean, 1959; Ripoll Perello, 1967; D'Arragon, 1997; Arca, 2002). In the South of France, this art has been shown in the Ariege Pyrenees, Oriental Languedoc, in the Dauphine area and of course in Provence. The most important sites being recorded are gathered in eastern Rhône (Hameau, 1995).

The schematic art is commonly dated between the late Neolithic - Chalcolithic and Bronze Age. This allocation is based on a supposed contemporaneity between the paintings and engravings discovered in the south of France and the presence of movable relics in direct proximity. At the Grotta Scritta, in the absence of any archaeological context and relationships clearly defined between the patterns, paintings cannot be dated more precisely. It seems however that the representation of horses in the so-called two patterns of "riders" pulls up the chronology, as the presence of horses is not attested in Corsica before the Iron Age. These two figures could be slightly newer than other anthropomorphic representations (Weiss, 1998). We remind that in a context of an island particularly rich in rock art engraved patterns (e.g. sites of E Schippiate, Petra-Frisgiata, and Cambia), the Grotta Scritta is the only site hosting painted designs.

\subsection{Historic report of the works and studies conducted on the site}

Although the site has long been known by the local population (Kreuzer 1977), it was officially discovered by Roger Grosjean in the 50s (Grosjean, 1959). Following this initial study, several French and foreign archaeologists have visited and studied the site.

The first records of the painted motifs were published in the late $60 \mathrm{~s}$ and in the 70s. Significant differences exist between the different surveys (Grosjean, 1969; Beltran, 1968; Kreuzer 1977). Interpretations of chronological phasing patterns and proposals offered by different researchers are not always consistent (Grosjean, 1959, 1960, 1966, 1969; Gagnières, 1959; Beltran, 1968; Kreuzer, 1977; Ripoll Perello 1967). In 1997, as part of a collective research program dedicated to the rock art of Corsica, M.-C. Weiss realized with a team of 15 people, the first comprehensive study of the painted patterns of the Grotta Scritta I and proposed a chronological phasing (Weiss 1998, 2000). Secondary patterns (lines, dots) were also listed and the various figures and signs were interpreted. The Grotta Scritta is perceived as a kind of "showcase" for artworks, certainly made over a certain period, but reflects the same ideology, through renewed symbols (Weiss, 1998). Weiss also assigns the site a more religious function than pictorial. Subsequent to this study, further work will be spent or will quote the site (Lanfranchi, Weiss 1997; D'Arragon, 1997 Amadei, Ottaviani, 1999; Weiss, 1998, 2000, 2003, 2007; Arca, 2002; PecheQuilichini, 2003). In a paper from 2007, M.C. Weiss returns to the cohesion of the first three realization phases of the paintings of the Grotta Scritta I (stylistic group A) and highlights the stylistic links between the patterns of the Iberian Peninsula, Corsica, Provence and Sardinia, on the basis of similarities in the anthropomorphic downwards arms or the recurrent association between the signs (points) and anthropomorphic figures.

\section{RECORDING METHODOLOGY}

\subsection{Objectives}

In order to preserve the integrity of the site, non-destructive $3 \mathrm{D}$ data acquisition methods are required and the recording techniques are based on the use of measurements without contact (Burens et al., 2013). 3D scanning work of the Grotta Scritta was carried out by surveyors and archaeologists from Strasbourg (INSA Photogrammetry and Geomatics Group) and Toulouse (GEODE Laboratory) and aims processing 3D models from dense point clouds obtained by terrestrial laser scanning and photogrammetric surveys. These techniques enable a full $3 \mathrm{D}$ documentation, without contact with the surface of the rock-shelter, and have the advantage of ensuring a perfect preservation.

Currently, most 3D scanning projects combine laser scanning and terrestrial photogrammetry (Grussenmeyer et al., 2012).

Both techniques meet several objectives: 
- Conservation: to view any kind of alteration of the object surface;

- Valorization: allowing the full recording of the rock-shelter and the terrace in the front.

The upper decorated part of the shelter has been recorded in a very accurate way. The documentation will be used as basis for $3 \mathrm{D}$ virtual restitution, to make a detailed statement of painted signs and patterns, or realize facsimiles in resin using $3 \mathrm{D}$ printers in the future.

\subsection{Technical solutions used in the project}

Terrestrial laser scanning was conducted with a Faro Focus 3D S120 system (Fig. 2a). This scanner has a range of $0.60 \mathrm{~m}$ to about $100 \mathrm{~m}$ and includes an internal camera for the colorization of the point cloud. The measurement uncertainty given by the scanner manufacturer is $2 \mathrm{~mm}$ at $25 \mathrm{~m}$. The reader must be aware that this accuracy depends on several parameters as the type of measured surface, incidence of the measuring beam, etc. (Vosselman \& Maas, 2010). Miniaturisation $(5 \mathrm{~kg})$ and the flexibility of use of this laser scanner have allowed its implementation in a particularly restrictive context (scan stations within the narrow dome and rugged topography at a height of about $2.50 \mathrm{~m}$, presence of dense vegetation in the immediate vicinity of the site). Meanwhile, a photogrammetric survey was conducted from several tripod stations (Fig. 2b) with a Canon EOS 5D Mark II SLR camera and a set of calibrated lenses of 20, 24 and $105 \mathrm{~mm}$ used without auto-focus (i.e. the fixed focus mode was set up at various tripod positions).

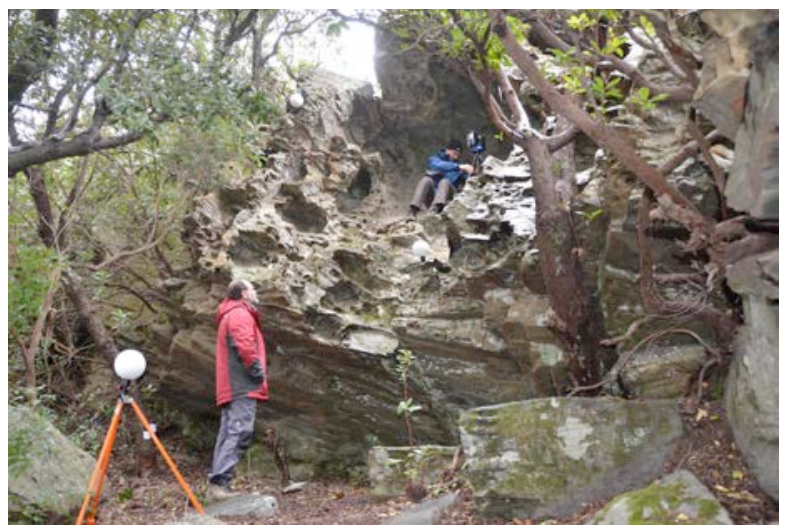

(a)

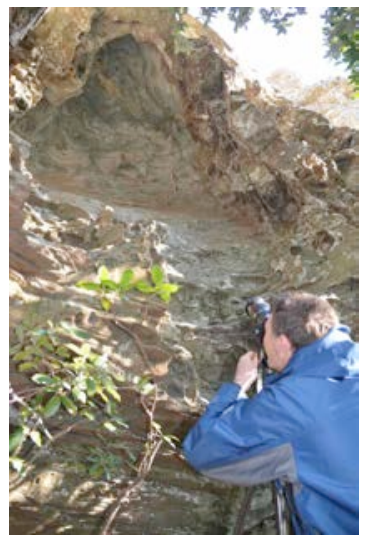

(b)

Figure 2. (a) Faro Focus 3D set up in the upper part of the rock-shelter; (b) photogrammetric recording at $7 \mathrm{~m}$ from the top of the dome (photos A. Burens)
Given the difficulties of access to the site, geodetic GPS antennas or total stations could not be carried on. Therefore the recordings have not been georeferenced accurately in position and height in the National reference coordinate system. A local network made of Faro spheres and targets was defined and used to adjust and merge the laser scanning and photogrammetric data. Some scale bars (Figure 3) were placed in the dome of the shelter to check the scaling of the 3D models. Point clouds, however, were oriented to the North with an accuracy of a few degrees with the help of the internal compass of the Focus 3D scanner.

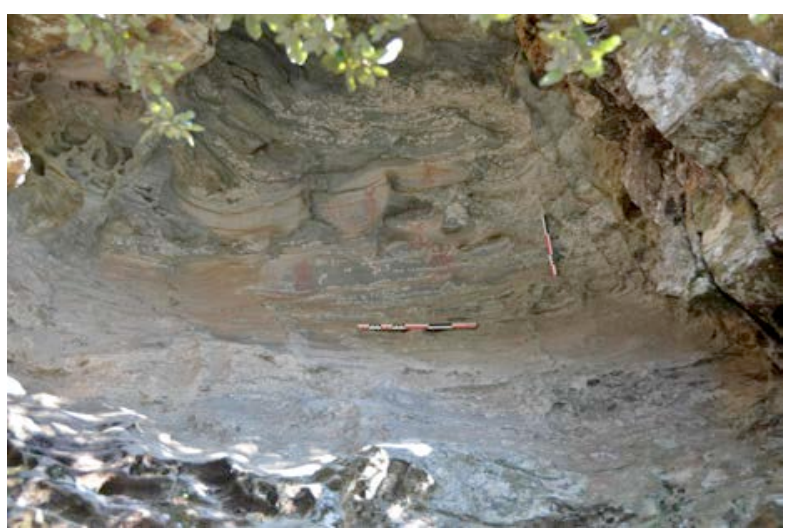

Figure 3. Upper part of the rock-shelter (dome) showing the parietal representations and the location of two scale bars

(photo P. Grussenmeyer)

\subsection{Data processing}

3.3.1 Terrestrial Laser scanning: Figure 4 shows the location of 13 scans spaced between 1 to $4 \mathrm{~m}$ and distributed on the whole site (Grotta Scritta1, terrace and Grotta Scritta2). Registration of the point clouds and colouring were done using Faro Scene software. After adjustment, the standard errors processed for the set of spheres are below 1.5 $\mathrm{cm}$. For the acquisition of point clouds, the scanner was set up with a spatial resolution of $6 \mathrm{~mm}$ at $10 \mathrm{~m}$, which given the distribution of stations provides a very dense point cloud. Segmentation and resampling steps have been made using the 3D Reshaper software.

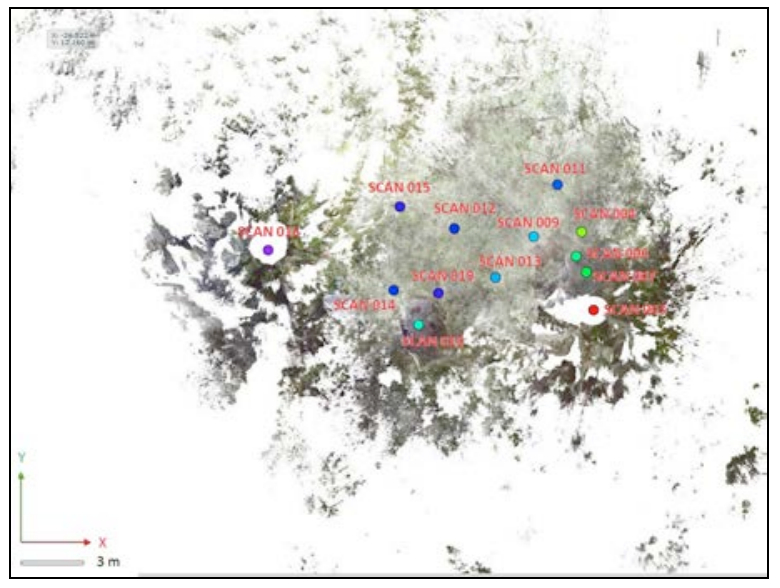

Figure 4. Layout the 13 laser scanning stations distributed on the Grotta Scritta site (top view).

Grotta1 (rock overhang): scans 004, 006 and 007. Grotta2: scans 012,014 and 019 
3.3.2 Photogrammetry: the photogrammetric survey was performed with several objectives:

- Produce a dense point cloud in order to complete the point cloud obtained by laser scanning (especially the portion of the dome of the shelter showing the parietal representations);

- Texture meshed models obtained by Terrestrial Laser Scanning;

- Create a catalog of images that follows the evolution of the shelter and the development of lichens on the rock.

The recording with an EOS5D Mark II SLR camera was organized in steps by placing respectively the tripod at $1 \mathrm{~m} \mathrm{(3}$ stations), $3 \mathrm{~m}$ (4 stations) and $7 \mathrm{~m}$ (5 stations) from the dome of the rock overhang and taking into account the best possible standpoint. A sequence of successive pictures was made from each station by imaging the visible side of the rock overhang (Table 1).

\begin{tabular}{|c|c|c|}
\hline $\begin{array}{c}\text { Fix Focus } \\
24 \mathrm{~mm}\end{array}$ & Object Pixel size & Number of images \\
\hline $1 \mathrm{~m}$ & $0,3 \mathrm{~mm}$ & 120 \\
\hline $3 \mathrm{~m}$ & $0,8 \mathrm{~mm}$ & 110 \\
\hline $7 \mathrm{~m}$ & $1,9 \mathrm{~mm}$ & 48 \\
\hline
\end{tabular}

Tableau 1. Pixel size in the object at various distances to the object with a focal length of $24 \mathrm{~mm}$ (EOS 5D Mark II SLR camera, 6,5 microns pixel-size on the sensor)

More photos were taken with a focal length of $105 \mathrm{~mm}$ but are not intended to be used for photogrammetric processing. For the scaling of photogrammetric projects, several solutions are possible:

- Setting the scale with simplified scale bars (shown in Figure 3);

- Manual measurement in the images of spheres and targets used in the laser scanning project (Figure 5);

- Identification of coordinates of control points in the point cloud from the Faro laser scanner.

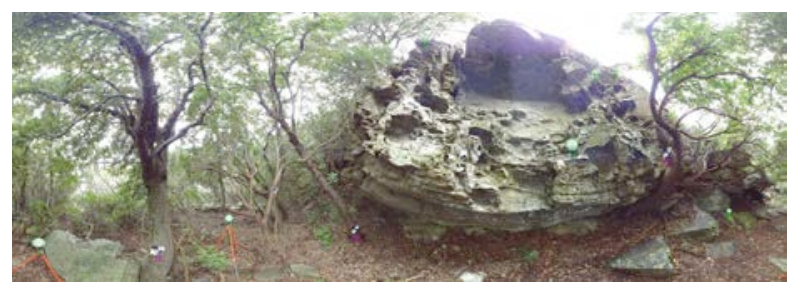

Figure 5. Distribution of the spheres and targets in a panoramic image generated by the Webshare of Faro Scene

\section{DELIVERABLES}

\subsection{Terrestrial laser scanning data}

After registration of the 13 scans displayed in figure 4 and before any pre-processing the raw point cloud represents 680 million points. After segmentation (removal of the vegetation), the initial cloud is reduced to 208 million points (which still represents $7 \mathrm{~Gb}$ in ACSII Format). The global cloud was finally segmented into several parts and resampled to be usable efficiently. For example, the colorized point cloud resampled to $1 \mathrm{~cm}$ (Figure 6) and limited to the sector of Grotta Scritta 1 contains about 1 million points (40 Mb).

\subsection{Photogrammetric data}

Photos of Table 1 were oriented using PhotoModeler and
PhotoScan software and scaled with control points measured manually on characteristic points of the rock shelter in the Faro Scene Webshare. The goal of the photogrammetric processing is to calculate accurately the position and orientation of the photos from the EOS 5D camera in order to use the oriented images for the texturing of the meshed 3D model. The calibration parameters of the camera (Incam) and the external orientation of photos (Excam) are thus exported from the photogrammetric software for further use with the 3D Reshaper texturing tools.

\subsection{D Models}

Several types of 3D models were calculated from the point cloud of the Grotta Scritta 1 resampled to $1 \mathrm{~cm}$. A first mesh was performed with the plug-in "Fish Surface Reconstruction" of CloudCompare 2.6 software, followed by a segmentation of the "closed" mesh produced by this algorithm. After this operation, a "Portion of Visible Sky" rendering was applied to visualize the shelter without texturing details (Figure 7).

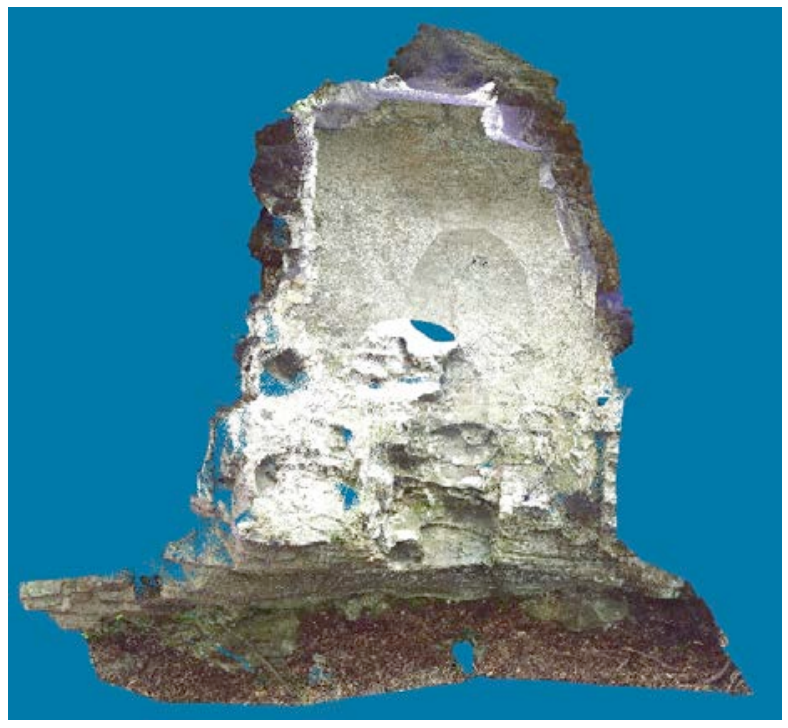

Figure 6. Coloured point cloud of the Grotta Scritta 1 (front view) resampled to $1 \mathrm{~cm}$ (see scale figure 10)

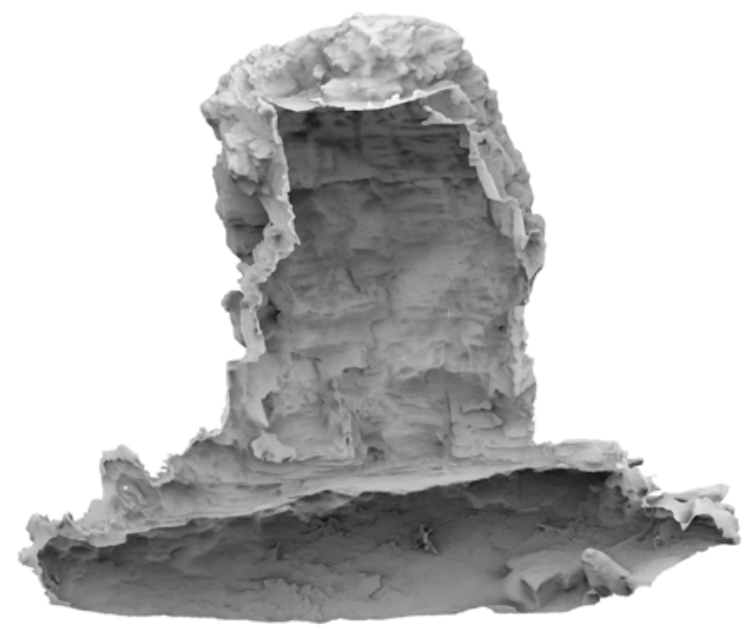

Figure 7. Meshed 3D model rendered with the "Portion of Visible Sky" plug-in from Cloudcompare 2.6 
Texturing based on photos from Canon EOS 5D SLR camera was performed in 3D Reshaper. Figures 8 and 9 are orthophotos from the projection of $3 \mathrm{D}$ information on a plan by considering a defined axis (in this case the viewing direction of the visitor towards the dome, in front of the decorated panel). The extraction of an orthophoto of the Grotta Scritta from the 3D model served us to record vectorized drawings of the paintings. The assessment of these drawings was achieved with in situ paintings in June 2015.

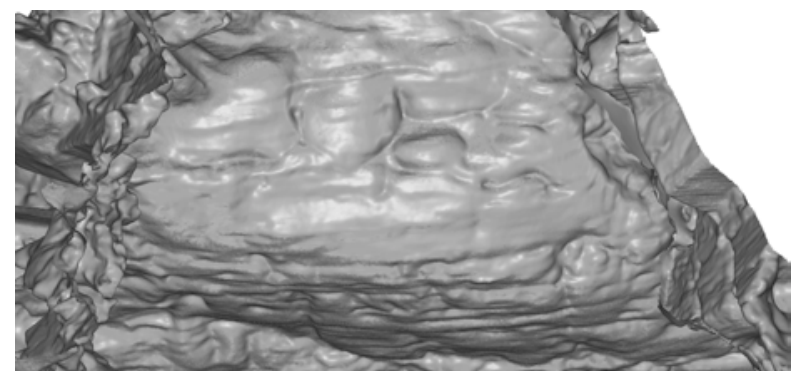

Figure 8. Orthophotos processed from the shaded 3D model enhancing the relief understanding (see the photo in Figure 3)

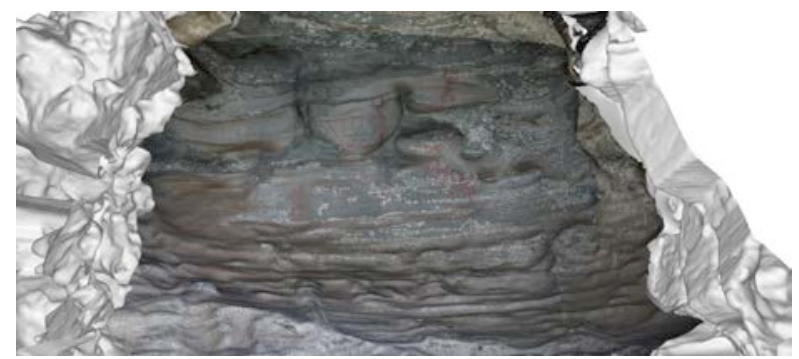

Figure 9. Orthopho processed from the textured 3D model

\subsection{Vertical and horizontal sections processed from the point cloud}

Vertical section (Figure 10) and horizontal ones (Figure 11) have been generated from the point cloud. These CAD 2D drawings have been processed from the tools offered by the CloudCompare 2.6 software.

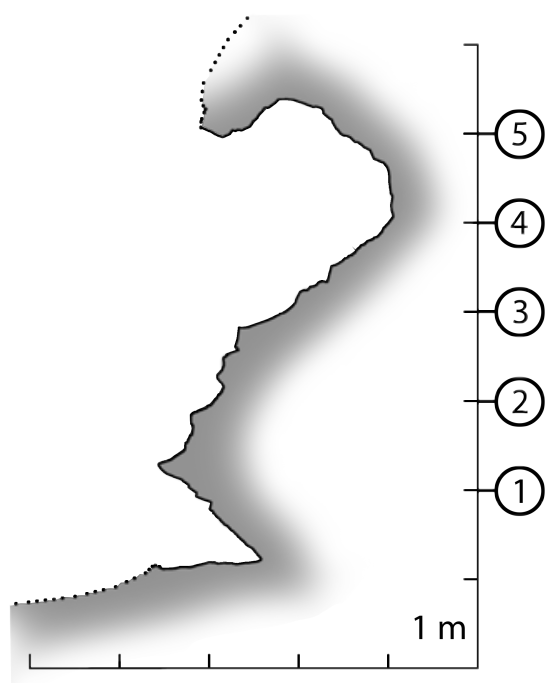

Figure 10. Vertical section of the rock-shelter. Parietal representations are located between horitontal sections 4 and 5 .

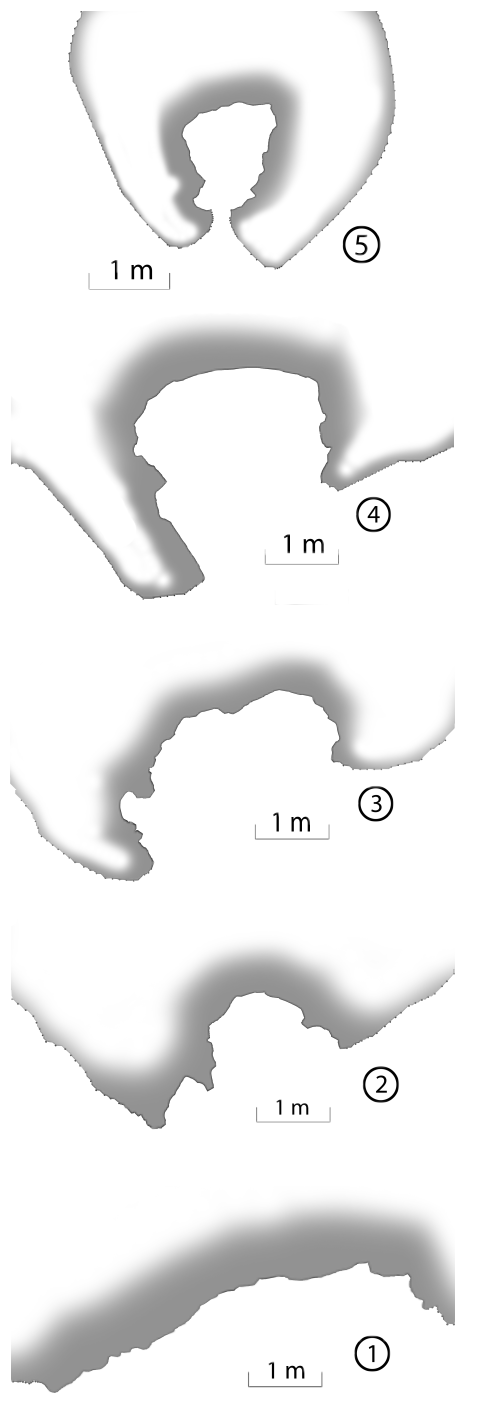

Figure 11. Horizontal sections of the shelter (see the location of the sections in Figure 10.

\section{CONTRIBUTION OF THE 3D DOCUMENTATION TO THE OBJECTIVES OF THE SITE STUDY}

As already mentioned, 3D scanning campaign performed in 2014 on the Grotta Scritta site was part of a process of preservation and submission of this exceptional site as an Historic Monument, at the initiative of the Territorial Authority of Corsica and the municipality of Olmeta-diCapocorso. The 3D modeling answers to the need for full high resolution documentation of this important site of the Corsican Cultural Heritage.

3D digital models do not constitute an alternative to the archaeological reality nor a substitute for traditional methods of documentation, but they are an interpretation of the reality and form a new type of documentation, complementary to photographs, allowing new forms of graphical representation and performing tools for the site study. In this sense they are part of the process description, understanding and interpretation of the complexity of archaeological sites (Campana 2014). At the Grotta Scritta, the resulting 3D modelling (based on hybrid models combining laser scanning and photogrammetry) can be understood as a relatively objective documentation, in the meaning that the site has not 
been the subject of archaeological excavations and the recording techniques developed are not invasive and have no contact with the shelter and rock paintings.

Beyond the traditional visualization and conservation purposes, 3D modelling of the Grotta Scritta will also be helpful to study the degradation process of the paintings in the dome of the shelter, particularly vulnerable due to the action of weather and anthropic degradation (deletions, graffiti). The first protective measures applied to protect the paintings from the joint action of the weather (rain, wind, sunshine) had indirectly encouraged the development of lichens on the decorated wall. This alteration, which had already raised the attention of M. C. Weiss during his inventory work realized in 1997 (Weiss, 1998), is the subject of a control since 2010. But the comparison between photos from Nicolas Mattei made in 1997 and the 3D model made in 2014 confirms the lack of real progress in the development of the lichens.

Moreover, the 3D model of the Grotta Scritta is a real tool to aid analysis and perception of the complexity of the volumes of the shelter, including the forms in the dome housing the paintings. From this point of view, 3D modelling brings real added value compared to traditional cartographic representations. The possibilities for interactive manipulation of the textured model by changing the lighting conditions but especially to display all or part of the signs are essential. Orthophoto from the 3D model was used (after a digital image enhancement processing) to support vectorized survey paintings. This technique allowed the development of a survey-independent perspective, combining high accuracy and metric restitution texture support (fig. 12). The resulting document is a significant contribution to the study of paintings because it provides a high degree of accuracy of the lichens development. The orthophoto has enabled an inventory of new points and spots (in the patterns 1, 10, 14 and 17) and confirms the presence (Figure 12) of an appendix missing in the survey published in 1998. Ocher casting has been revealed on the signs numbered 5, 11 and 12. Signs 14 and 15 , recently erased, can be considered as a single sign instead of two signs previously inventoried separately.

\section{CONCLUSION}

An overview of the 3D documentation project of the Grotta Scritta in Corsica (France) has been presented in this paper. Quality digital archives in the form of coloured point clouds and high-resolution photos based on current techniques of laser scanning and photogrammetry are now available for this site. Modelling examples demonstrate that one can generate different types of 3D models to facilitate the understanding of the site. Thus, the 3D model is an interpretation of the archaeological reality and forms a new type of documentation, complementary to photographs, allowing new forms of graphical representation and motivating new ways to take future actions. Today, the Grotta Scritta is a vulnerable site, made fragile by the action of time and man. The recordings acquired on this site owned by the municipality in 2010 now allow initiating the process of conservation and protection. The application to prepare the site classification request as an Historic Monument is in progress.

\section{ACKNOWLEDGEMENTS}

The team thanks the Regional Conservator $\mathrm{Mr}$ Franck Léandri from the Regional Office of Archaeology and Mrs Mireille Boncompagni, Mayor of the municipality of Olmetadi-Capocorso for their confidence and support throughout this project.

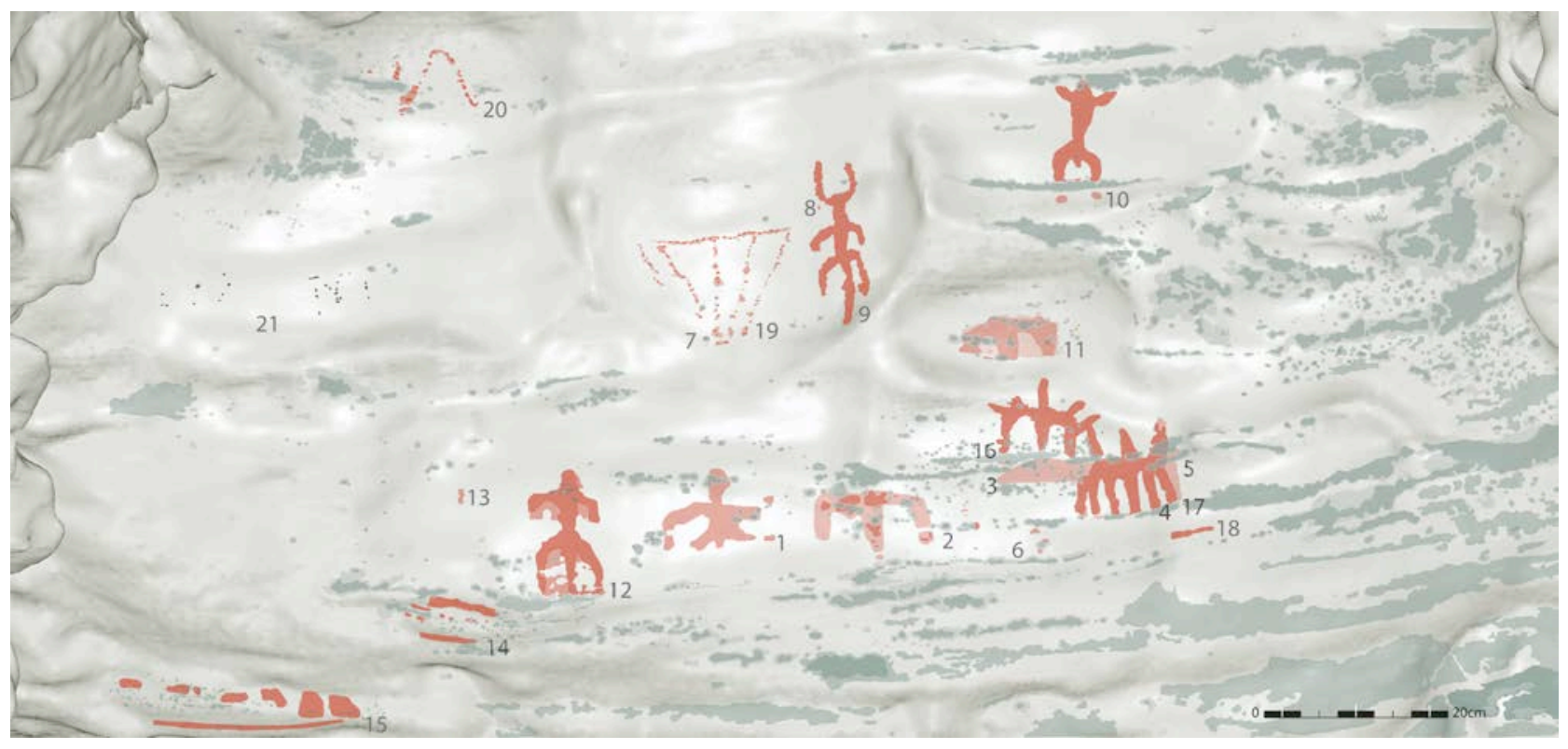

Figure 12. Drawings of the parietal representations visible in the Grotta Scritta 1 (Olmeta-di-Capocorso, Corsica, France). In red: painted elements $\left(n^{\circ} 1\right.$ à 20$)$; in grey: modern graffiti $\left(n^{\circ} 21\right)$; in grey-green: lichens. The recording is based on orthophotos processed in Figures 8 and 9. 


\section{REFERENCES}

Amadei, A., Ottaviani, J.-C. 1999. Les peintures rupestres d'Olmeta du Cap. In: Le mémorial des corses. Dir. Arrighi, Jean-Marie et Vinciguerra, Marie-Jean, T.3, 1999, p. 48.

Arca A., Gambarin, F. M., 2002. Influenze mediterranee nelle pitture nel Neolitico finale in piemonte. In: Il declino del mondo neolitico. Richerche in Itlaia centro-settentrionale fra aspetti peninsulari, occidentali e nord-alpini. Atti del convegno (Pordenone, 2001), Quaderni del Museo Archeologico del Friuli Occidantale, 2002, 4, p. 421-425.

Beltran Martinez, A., 1968. Breve nota sobre tres nuevos abrigos con pinturas de la Etad del Bronce en eceite (Teruel), Villafames (Castellon) y Olmetta du Cap (Corcega). In: La Préhistoire, problèmes et tendances. Paris : CNRS, 1968, p. 19- 24

Burens, A., Grussenmeyer, P., Carozza, L., Leveque, F., Guillemin, S., Mathe, V. (2014). Benefits of an accurate 3D Documentation in Understanding the Status of the Bronze Age Heritage Cave „Les Fraux" (France). International Journal of Heritage in the Digital Era, ISSN 2047-4970, Vol. 3(1) : 179-196. DOI: 10.1260/2047-4970.3.1.179.

Campana, S., 2014. 3D Recording in Archaeology and Cultural Heritage - Theory and best practice. In : F. Remondino, S. Campana ed. : 3D Recording and Modelling in Archaeology and Cultural Heritage - Theory and best practices. BAR International Series 2598, 2014, p. 7-12.

D’Arragon, B., 1997. Nuove figure schematiche antropomorfe dalla Sardegna prenuragica: le pitture rupestri della Grotta del Papa, isola di Tavolara (SS - I) Sardinia Sardegna. 2nd International Congress of Rupestrian Archaeology. 2-5 Darfo Boario Terme, October 1997.

Gagniere, S., 1959. Aix-en-Provence. In: Gallia Préhistoire. T. 2, 1959, p. 252.

Grosjean, R., 1959. Les premières peintures rupestres de Corse. Chronique d'Archéologie Préhistorique. Etudes Corses, 1959, 22, p. 77-78.

Grosjean, R., 1960. Rapports Corse-Sardaigne-Pouilles - Art et monuments circulaires du Bronze moyen. In BSPF, $\mathrm{n}^{\circ}$ 5-6, volume 57, Informations - Communications, 1960, p. 296.

Grosjean, R., 1966. La Corse avant l'histoire. Paris: Klincksieck, 1966, 95 p.

Grosjean, R., 1969. A propos de l'article d'A. Beltran, de Saragosse, sur les peintures rupestres de la Grotta Scritta (Olmeta du Cap Corse). Comptes rendus des séances mensuelles. Bulletin de la Société préhistorique française, 1969, T. 66, p. 132-133.

Grussenmeyer, P., Alby, E., Landes, T., Koehl, M., Guillemin, S., Hullo, J.-F., Assali, P., Smigiel, E., 2012. Recording approach of heritage sites based on merging point clouds from high resolution photogrammetry and terrestrial laser scanning. 22nd ISPRS Congress, Melbourne, 25-31 August, 2012. Int. Arch. Photogramm. Remote Sens. Spatial Inf. Sci., XXXIX-B5, 553-558, 2012.

Hameau, Ph., 1995. Les peintures postglacaires en Provence. Inventaire étude chronologique, stylistique et iconographique. Documents d'archéologie Française, $n^{\circ} 22$, ed. de la Maison des Sciences de l'Homme, Paris, $124 \mathrm{p}$.

Kreuzer, G., 1977. Die felsbilder Korsikas, Antike Welt, zeitschrift für archäologie und kulturgeschichte. $n^{\circ} 2$. 1977, p. 61-62.

Lanfranchi, F. (de), Weiss, M. C., 1997. L'aventure humaine préhistorique en Corse. Ajaccio : Albiana, 1997, 503 p.

Peche-Quilichini, K., 2003. L'art rupestre de la Corse : essai de mise en relation iconographique et technique avec les grands sites de Méditerranée occidentale, Bulletin d'Archéologie et d'Histoire de la Corse, 1, 2003, p. 16-37.

Ripoll Perello, E., 1967. Nota acerca de las pinturas rupestres de la grotta Scritta en Olmeta-du-Cap (Corcega), revue Ampurias. XXIX, Barcelona : (s.n.), 1967, 262-267 p.

Vosselman, G. and Maas, H.G., (Eds), 2010. Airborne and Terrestrial Laser Scanning. Whittles Publishing, ISBN 9781904445-87-6, 336 pages.

Weiss, M. C., 1998. Préhistoire de l'art corse : les peintures rupestres d'Olmetta du Cap, département d'archéologie expérimentale et de moulage, université de Corse. Bastia : Siciliano, 1998, $61 \mathrm{p}$.

Weiss, M. C., 2000. Nouvelle lecture des peintures rupestres préhistoriques d'Olmeta-du-Cap et étude de deux mocreaux récupérés de la statue-menhir de Renno. Rencontres Méridionales de Préhistoire Récente. Troisième session, Toulouse 1998, Ed. Archives d'Ecologie Préhistorique, 2000, p. $257-263$.

Weiss, M. C., 2003. L'art rupestre de la corse è petre scritte. Ajaccio : Albiana, 2003, 241 p.

Weiss, M. C., 2007. L'art rupestre de la Corse. In : Corse et Sardaigne préhistoriques - relations et échanges dans le contexte méditerranéen. Dir. André D'Anna, Joseph Cesri, Laurence Ogel, Jean Vaquer. CTHS, 2007, 185-195 p. 